\title{
The Vacant Urban Space: Problems, Possibilities, Processes
}

\author{
Mariann Simon ${ }^{1 *}$, Amine Mseddi $^{1}$ \\ ${ }^{1}$ Department of Urban Planning and Design, Faculty of Landscape Architecture and Urbanism, Szent István University, \\ Villányi út 35-43, H-1118 Budapest, Hungary \\ * Corresponding author, e-mail: Simon.Marianna@tajk.szie.hu
}

Received: 13 February 2020, Accepted: 27 July 2020, Published online: 18 August 2020

\begin{abstract}
Cities are dynamic entities in perpetual evolution. Through this process, vacant spaces tend to appear under different circumstances. Certainly, empty and abandoned lots in a dense urban fabric are easily locatable. That their state persists over a considerable period is what makes them remarkable. This phenomenon may be viewed from different perspectives by urban planners, architects, geographers, economists, environmentalists, sociology academics and policymakers. Therefore, multiple data, parameters and definitions are in play. This multidisciplinary combination could quickly create a terminology issue in the scientific body related to urbanism and open space design. This paper presents an overview of the definitions of urban vacant spaces, taking into consideration the various perspectives. While following the timeline and the changes in the interpretations of the vacant urban space, it becomes evident how this phenomenon came from a problem of failed urban design to a possible place of resistance and finally an accepted possibility for temporary urbanism.
\end{abstract}

Keywords

vacant urban space, urban transformation, temporary use

\section{Introduction}

It is well known among urbanists and open space designers that cities are dynamic entities in perpetual evolution. Through this process, empty spaces tend to appear in different circumstances. Undoubtedly, empty and abandoned lots in a dense urban fabric are easily locatable. That their state persists over quite long times is what makes them remarkable. There are, indeed, multiple reasons behind the actual shape of these urban voids. However, certain patterns that lead to this state can be detected, since this phenomenon can be perceived from the varying perspectives of urban planners, architects, geographers, and sociology academics. Therefore, multiple data, parameters and definitions are in play. This multidisciplinary combination could quickly produce a terminology issue in the scientific body related to urbanism and open space design. A terminology that should be determined to ensure more efficient investigations, analysis and approaches towards the consideration and usage of vacant urban spaces.

This paper presents an overview of the definitions of urban vacant spaces, taking into consideration the different perspectives. How do scientists define empty urban spaces? What could be considered as vacant urban land? Would a definition be reductive or helpful in order to confront this urban feature? Is there a need for a classification? On what basis should urban spaces be categorised? How has the perception of vacant spaces changed over time?

\section{The vacant urban space}

As a starting point, deconstructing the term is an effective way to simplify the definition process. A "vacant-urban-space" is defined firstly by being a space. It is a vague term with multiple physical, philosophical and psychological interpretations, but in this case, can be simplified into a delimited three-dimensional physical area as a part of a bigger system, which is, in our situation, an urban system. Qualified as urban, it means that it belongs to a city fabric as an element of its configuration. In urban studies, urban space is mainly an outdoor space contributing to city structure, communication, and social interaction. Urban is typically used as opposed to rural; it may be public, semi-public and private. Then, the adjective vacant is added; and again, we are facing another vague term with different interpretations, from a physical void, an architectural/urban void, or a metaphysical void.

A void usually refers to the lack of something. In this case, it could refer to the lack of physical entity as a 
built structure or a natural element or even both. It could refer to the lack of an attributed function for some reason regardless of physical presence. It could be the lack of users or activities space despite the existence or not of a function or a physical entity.

However, the term vacant, while connected to space, area, land or a plot often carries a negative connotation, creating a social, mental image of dereliction, decay, loss and danger; an image that is often reflecting the reality of these perceived spaces. This factor seems to have an additional dimension within the definition of vacant urban space.

As this issue is seen from different angles, this review will examine the different perspectives from the broader conceptual and economic aspects to those more connected to urbanism and open space design.

\section{A current general overview of the topic}

An exhaustive bibliographic analysis of the period 1964 to 2014 was carried out by a team of researchers from urban and regional science, urban planning, and political science and management; the aim, using the different academic and professional sources, was to determine several definitions for the term "vacant urban land" (Newman et al., 2016). A collection of definitions and descriptions were put in chronological order, allowing the reader to follow the evolution of the definition process as well as the different results.

The definitions continue to evolve. With the development of scientific research and the appearance of new interdependent specialities, different definers from multiple backgrounds could not provide the same definitions, referring to the priorities presented by their fields. On the one hand, what could be an asset is the common points that could form a basis for the definitions. On the other hand, the singularity of each attempt is also essential for the classification based on those differences, which creates a clearer view on the topic and a more methodical way to approach the issue and solve the problems that it presents.

Multiple definitions were being used to try to determine what is meant by the term vacant land, or simply VL. They vary from very broad (undeveloped and are not underwater) to less general (brownfields/empty lots/green fields/, physical limitations) to more specific (vacant for two years or more/60 or 120 days or longer, public or private ownership, number of buildings, legal structure). Other factors are involved in this multiplicity. The definitions are variable according to the perspective of the definer, including the physical manifestation (not underwater, parcel, structure, physical limitation); the morphology (razed, destroyed land, land with vacant building, undeveloped); the legal situation (no lawful structure, policy aided, converted land, publicly-owned and privately-owned, institutional reserve, held for speculation); the economic value (below capital-producing capacity, not actively used); and even the history (recently cleared, once had a structure, successional converted). However, though the definitions vary, they insist on a common character: neglected, underused or unused, derelict, abandoned, uncultivated, has no use, no purpose.

The study also involves a classification based on these definitions. Each term has significant characteristics, reflected in the real physical and geographical context. This classification is based on different parameters depending on the point of view of the various disciplines working on this phenomenon. These parameters vary from land morphology (bare/vegetated, empty/with architectural structure; vacant structure/destroyed) to land use (abandoned/unused/trash dump/temporary use/transitional situation); history (previous function and time of abandonment), and other impacts (health hazards, social discomfort, environmental abuse).

In conclusion, the mostly negative markers suggest that, according to the authors' field (urban and political science and management), vacant spaces should be eliminated. However, it is important to note, that the analysed research concentrated on American cities and intended to discover the relationship between the changing rate of urban vacant land of a given city and its relationship to economic factors, city policy and population movements.

\section{Lost space as an urban problem}

The first book that touched on the topic of vacant space from an urban perspective was written by the American architect and landscaper Roger Trancik (Trancik, 1986). He placed the focus on urban spaces that were designed and subsequently became distasteful unfriendly sites. Besides the definitions and the causes, the book explains the development of the $20^{\text {th }}$-century space with robust case studies in Boston, Washington, Goteborg and Newcastle that introduce his analysis. The book also discusses the value of what he likes to call "lost spaces" and urban spatial design theories.

To have accurate defining results, Roger Trancik starts with a series of observations allowing him to discover a broad spectrum of lost spaces. Within the description, different features appear in the analysis: leftover 
unstructured landscape, unused plazas and parking lots (away from flow and activity), abandoned waterfronts and train yards, vacated military sites and industrial complexes, remnants of urban renewals, residual areas in between districts and blocks, and deteriorated parks.

These forms of lost spaces show three main characteristics: first, they are unwanted or unplanned. We can see through the vocabulary used by Trancik (1986), "leftover, residual, remnant, unused, abandoned, deteriorated", that these spaces have failed the users to some level. He highlights the character of decay, neglect and rejection. Secondly, they have negative urban input, or at least no positive role connecting the surroundings or maintaining the city structure even in the case of attributed but underutilised function. Usually unstructured, they are poorly framed, and they tend to spread spontaneously. Finally, they have no clear limits. Lost spaces are considered as a major symptom of urban degeneration. Trancik described these urban vacant spaces as follows: "Urban voids are undesirable urban areas that are in need of redesign, anti-space, making no positive contribution to the surroundings or users. They are ill-defined, without measurable boundaries and fail to connect elements in a coherent way" (Trancik, 1986:p.12). Nevertheless, he claimed that these spots offer huge opportunities for urban redevelopment, creative refill, adaptive reuse and potential discovery.

Besides the lost spaces with a negative connotation, Trancik introduced another aspect of the urban void; namely, the designed void, in contrast with "urban solids": the built structure in the city. He divided these voids into five major types. These categories mainly refer to the well-known solid-void duality introduced by Colin Rowe and Fred Koetter, whose theory Trancik devotes a whole chapter (Rowe and Koetter, 1978). As first, Trancik (1986) names the entry foyer that establishes the vital transition, or passage, from a personal domain to a common territory. Considered as a small architectural detail, this type has its importance in its transitional aspect. The second type on the author's list is the inner block void, the enclosed "hole in the doughnut", a semiprivate residential space for leisure or utility or a midblock shopping oasis for circulation or rest. This void is usually not open to the public but is intrinsically functional.

The next three items reflect more on the urban scale. "The network of streets and squares, a category that corresponds to the predominant field of blocks and that contains the active public life of the city" (Trancik, 1986:p.103). He states that although throughout urban history, this network functioned as the principal structure for civic design and spatial organisation, today it no longer serves this role. The fourth category is public parks and gardens, a type of larger void that contrasts with urban architectural forms. Their primary role is to preserve nature in the city. They are implemented into the urban structure to imitate rural atmosphere, providing recreation and softening the dense rigidity of the urban environment. Finally, Trancik lists "the linear open-space system, commonly related to major water features such as rivers, waterfronts, and wetland zones" (Trancik, 1986:p.105).

Trancik underlined the importance of these designed, urban voids and drew attention to the risk of neglecting them and becoming among the lost spaces. In which case, these spaces, especially the public designed ones, would fall under three main categories: planning voids created due to flawed planning process, functional voids created due to unused space or a built mass that has become defunct, and geographical voids as a result of a geographical feature (hill, canyon, riverside) or a natural disaster.

Trancik's categorisation of how a designed void can turn to a lost space was based on a background of indirect causes (Fig. 1). The author sums them up as five significant factors including the dominance of the automobile (huge space for movement and storage), the modern movement in design that focuses on buildings as separate objects with no real consideration to the harmony within the context, the zoning and urban renewal policies, the privatisation of urban space (same modern movement approach), and lastly the pervasive change in land use.

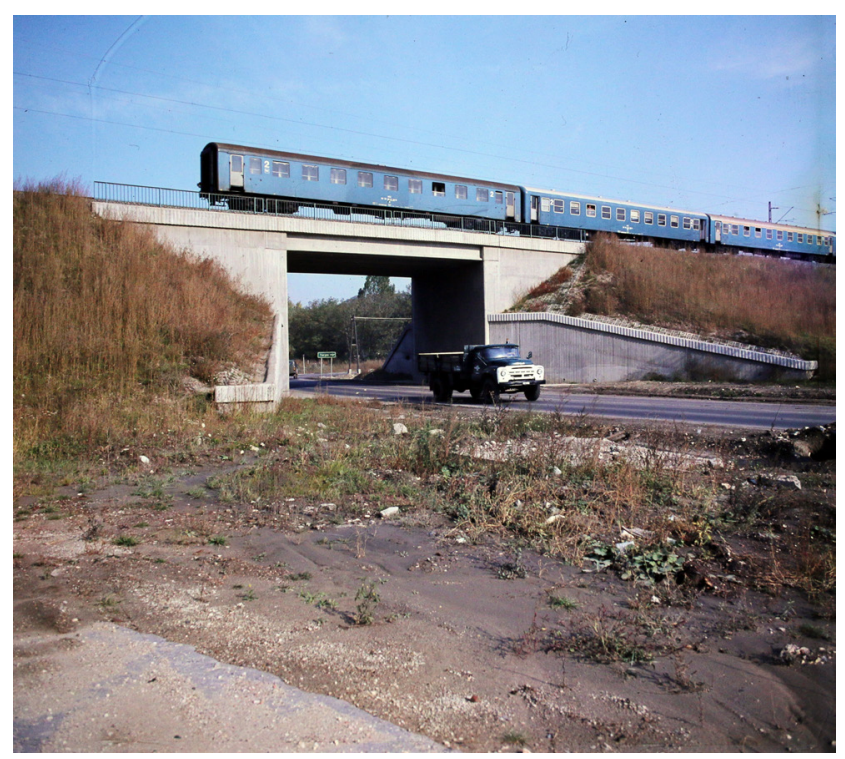

Fig. 1 Railway overpass on the Budapest-Györ line (Source: Fortepan, 1980) 
Having a futuristic perspective on this issue, Trancik does not stop at describing and analysing the problem but tends towards presenting a way out of it. As mentioned before, he sees in these vacant spaces an opportunity for urban regeneration and adaptive reuse. In order to achieve this, he proposed a three-step method: first, by studying the historical precedents of the space as well as the urban evolution of the modern city fabric; this helps to reach the second step: understanding the theory of urban spatial design that enables matching the given situation. Finally, developing skills to synthesise and apply the theories is the key to pass from the theoretical to the concrete frame. These lost spaces are eager to play an important role in city growth and development. They present a subject for debate based on the value of the space (economic, ecological and historical) and its future destination while taking into consideration the possibility of a better understanding and new ideas.

To conclude, Trancik approaches the problem from an architect/urbanist point of view. The definitions originate from a general observation of the morphology of the space as a physical element. Then, he underlines the character of disconnection in relation to the urban and architectural elements, abandonment and non-use. The crucial, economic aspect is present, yet, he is mainly focusing on the role of the planner, analysing the causes, presenting solutions and proposing a new rethought concept.

Trancik's "lost spaces" are urban open spaces, which are vacant because they fail to attract people; people do not use them. From the point of an urban designer, their emptiness or vacancy is an urban problem that should be solved by design.

It should be mentioned that in the same year that Trancik edited his book, the Council of Europe launched its Recommendation No (86)11 on the role and importance of urban open space. "Open space expresses the collective life of the city and acts as an element of social cohesion. It is a sort of public living-room for the locality" (Council of Europe, 1986:p.4).

\section{Vacant space as an urban possibility}

Only a decade after Trancik's invention of space as a by-product of modern urban planning, the theme popped up again but with a somewhat different approach. It was the Catalan architect and theoretician, Ignasi de SoláMorales who alluded to the importance of terrain vague in his essay. Analysing city architecture he concluded, that, by the end of the millennium, architecture will have created containers (museum, stadium, shopping mall, theme park, tourist centre) that generalise separation from the city. "Separation from reality in order to create, perfectly explicitly, a space of representation. Physical separation denying permeability, transit, transparency" (de Solá-Morales, 1996:p.20).

These artificial public spaces are more ritual than functional, and as such, they express an imagined, idealised world. However, the reality of cities is much different. "Areas abandoned by industry, by the railways, by the ports; areas abandoned as a consequence of violence, the withdrawal of residential or commercial activity, the deterioration of the built fabric, residual spaces on the banks of rivers, rubbish dumps, quarries; areas underutilised because they are cut off by motorways, on the fringes of housing developments that are closed in on themselves, with access tightly restricted for putative reasons of safety and protection" (de Solá-Morales, 1996:p.23). These are the characteristics of de Solá-Morales' terrain vague, who uses the French expression to avoid the negative connotation of its English translation the "vacant land". Terrain vague is void, unproductive but at the same time, it is undefined, has no clear future, whatever may happen there (Fig. 2). These places offer a possibility, a promise for something better, "the last uncontaminated redoubt in which to exercise the liberty of the individual or the small group" (de Solá-Morales, 1996:p.23).

De Solá-Morales' radical call for the invention and acceptance of terrain vague for a place, which is still (seems to be) free of the mediatised capitalism, can be interpreted as a reaction against the all-embracing globalisation and the practical parallel turn of architectural theory. The Catalan architectural theoretician was not alone with his approach in the "anything goes" decade of the 1990s.

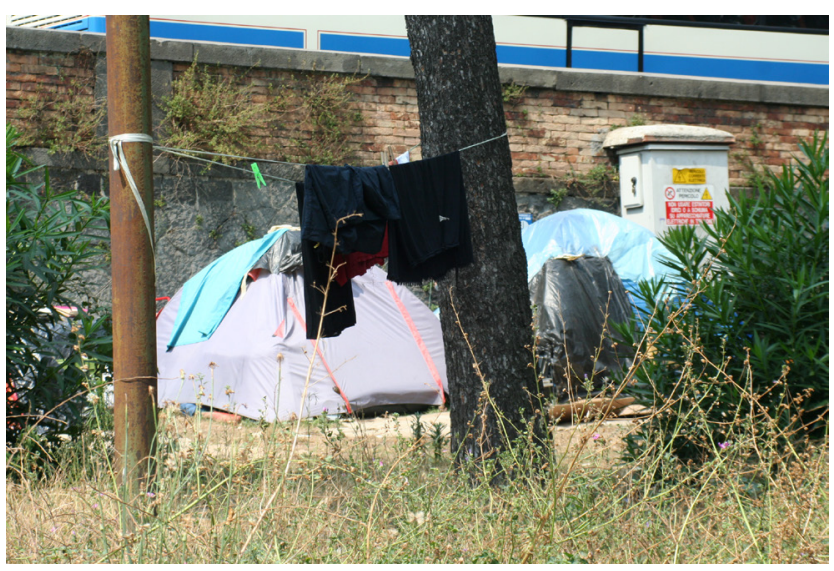

Fig. 2 Homeless people tents at the Molosiglio Park, Naples (Source: Mariann Simon) 
Henri Lefebvre's book "The Production of Space" came out in 1991, and his collected writings on the city were translated into English in 1996 (Lefebvre, 1991; Lefebvre et al., 1996). This second collection of writings published the philosopher's much earlier book, The Right to the City. The ideas that were initially formulated during the Parisian students' revolt in 1968 became timely almost thirty years later. While Lefebvre puts the question: "What are and what would be the most successful places?", he also mentions the potential inherent in the voids. These voids appear in social structure, but if we accept that space is created by people, the "holes and chasms" in society are in parallel with spatial voids. "Considered as a whole, this society find itself incomplete. Between the sub-systems and the structures consolidated by various means (compulsion, terror and ideological persuasion), there are holes and chasms. These voids are not there by chance. They are the spaces of the possible" (Lefebvre et al., 1996:p.156).

Lefebvre's three categories of how we approach space perceived, conceived, lived - already expressed a break with the binary logic, and they soon served as a starting point for Edward W. Soja for his thesis on spatial triads, which he elaborated in the book "Thirdspace: expanding the geographical imagination" (Soja, 1996).

Soja develops his interpretation of the "thirdspace" from Lefebvre's lived space as a combination of the real and the imagined, which foregrounds dominance and resistance both. "Combining the real and the imagined, things and thought on equal terms, or at least not privileging one over the other a priori, these lived spaces of representation are thus the terrain for the generation of 'counterspaces', spaces of resistance to the dominant order arising precisely from their subordinate, peripheral or marginalised positioning" (Soja, 1996:p.68). In the further elaboration of the thirdspace, the inherent oppositional features are more explored like choosing marginality as a space of radical difference.

In conclusion, the architect de Solá-Morales' definition of terrain vague or the philosopher Soja's "counterspace" describe another interpretation of the vacant space. In their interpretation, the attributive vacant refers to a space that offers the possibility of escape and resistance.

\section{Vacant space as an urban reality}

The architectural approach to vacant urban spaces has changed for the millennia. The empty spaces and vacant buildings became an accepted reality, but a situation that needs to be addressed. Today, the topic has touched not only urbanists but has become widely recognised among landscape designers (Woolley, 2003). The unused urban space is no longer considered either a failure of urban planning or a place for social resistance.

Merten Nefs attempts to do this in his study (Nefs, 2006). The architect-urbanist author distinguishes vacant terrains and vacant buildings. The built and unbuilt character is a primary criterion to frame the case, even though they both share the decayed and deteriorated aspect. A second important distinction is made on a historical basis: a factor well elaborated and justified by the successive circumstances and the development pattern of the surrounding. It leads to two main options: the vacant space which has been there since the city formation, and the vacant space that had a previous function. However, after analysing some European and South American city developments around the millennia, Nefs concludes that urban vacancy, temporary use and re-occupation is, in fact, a cycle that guarantees flexibility for urban development. This means that unused urban space is valuable. To define or estimate the value of vacant urban space the author sets a starting point, which is their known value, including the present state, and the hidden potential for the future design of these parcels.

As the most evident, he lists the use-value of such a lot from the point of view of the potential users and the exchange value from that of the real estate owners. These two aspects together cover the economic value. The economic value contains the use value from the citizens perspective when considering the eventual functions, in addition to the exchange value (or the capital creation value) from real estate speculators perspective. This category is based on economic aspects and speculation, which makes it more tangible and concrete.

The other values such as historical, cultural and ecological values are intangible, difficult to quantify. The historical and cultural value of empty spaces can be subject to several interpretations, evaluations, and polemics, which makes it more open to debate. Economic, historical and cultural values coincide in some cases, so the revitalisation of derelict spaces is included in the city development plan, which also considers the intensity of open public spaces and the possibility for improving the pedestrian network (Maric and Djukic, 2018).

At first glance, environmental values seem more evident, although they result in a significant debate regarding unused urban space. For example, if an urban wasteland should be protected as nature reserves or converted into an 
urban park. Based on the presented and analysed examples and facing the different and changing interpretations of the historical and environmental value of urban vacant spaces, Nefs arrives at the concept of temporary use. While he mentions it as a practice and possibility, he expounds its advantages and problems only in the case of vacant buildings.

However, the temporary use of vacant urban space as a practice and a newly accepted trend soon became widespread (Fig. 3). The 2012 book, "The Temporary City", compiled by the urban planner Peter Bishop and environmental scientist Lesley Williams, outlines a greater appreciation for immediate outcomes and temporary activities among planners, architects, developers and city officials (Bishop and Williams, 2012). They were preceded by the participants of the Urban Catalyst project who had already started their research in 2001 but edited a collection of their experiments and case studies only in 2013 (Oswalt et al., 2013).

By this time, not only had several projects been realised, but the world also found itself in an economic crisis, which enhanced the interest in cheap solutions. Ironically, as Kees Christiaanse remarks in his introduction, that while the initiatives of temporary use are particular, they have a public character and as such a kind of identity, often becoming a city attraction. "While cities still liked to adorn their advertising brochures with classic investor projects until well into the 1990s, today, one finds attractive illustrated descriptions of a 'creative micro-milieu of temporary users', small businesses and start-ups from the area of the so-called creative economy" (Oswalt et al., 2013: p.13).

As these examples show, the theme of vacant spaces for temporary use touched urban planners, architects and investors alike. However, it should be noted that the examples and projects mainly concentrated on vacant urban spaces, and not on vacant urban land. A study from 2014

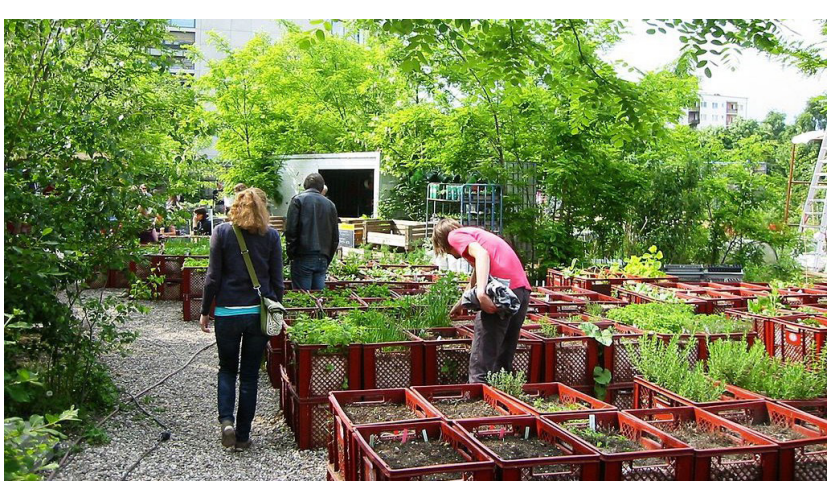

Fig. 3 Planting in pots for temporary urban farming in Prinzessinnengärten, Berlin (Source: Assenmacher, 2011) covers both kinds of urban vacancy for temporary use (Németh and Langhorst, 2014). The authors give an overview of the different approaches and subsequent definitions of urban vacant land. As a result, they separate four approaches to temporary use as political, economic, social and ecological. In the following, they analyse the conditions of temporary use for the previously defined aspects. Compared to Nefs's study (Nefs, 2006), temporary use came from an occasional solution to an accepted mode of use. The political and economic aspects were separated, and the historic-cultural value turned to the social one. Based on several previous projects, the authors refer to advantages and problems alike. "Although many examples of temporary use are considered 'activist' or 'counter-cultural', activities such as urban agriculture are quickly losing their transgressive image, legitimising the people that engage in such activities. This legitimisation - whether welcomed or not - is challenged if temporary uses are suspended in favour of more profitable endeavours, defeating the hopes of communities frequently already victimised by the processes of uneven development, and conceivably disenfranchising them even further from participating in the discourses on the future of their neighbourhoods" (Németh and Langhorst, 2014:p.148). Against the inherent and already occurred problems of temporary use of urban spaces from the social aspect, the authors celebrate ecological aspects. They include in this block not only such large territories like brownfields or urban edges but calculate on a different scale. "Consequentially, the temporary use model needs to operate on multiple scales, from an individual lot to a block to a neighbourhood to a city-wide or even regional scale" (Németh and Langhorst, 2014:p.148).

The ecological aspect of temporary use increased over the last decade. Some writings in the 2010 book Ecological Urbanism (Mostafavi and Doherty, 2010), already touched on the topic but since then there have been studies published, which concentrated on urban vacant land primarily as an ecological potential. (Kim, 2016; Kim et al., 2018). The authors categorise the vacant urban lands according to physical, biological and socio-cultural characteristics; however, the main proposal leads to a listing according to "how urban vacant land can function as green infrastructure that provides ecosystem services and social values for the local community" (Kim, 2016:p.16).

The millennium brought a new interpretation of the term "vacant urban space". It has been introduced into the discussions and used as a synonym for empty or unused open space considered as an urban reality; an adaptable 
space, which is unrestricted and used for a variety of functions, ad hoc as well as planned.

\section{Conclusion}

Today, vacant urban space has developed into a key problem for architects, urban planners and landscape architects equally. In a recent overview of the urban design of the $20-21^{\text {st }}$ Century, the authors conclude that Landscape Urbanism is a current trend, but before that, they devote a whole chapter to Urban Voids and "in-between" Landscapes (Díez Medina and Monclús, 2018).

Unused urban spaces were already a problem in the 1980 s, as a reaction to the visible failures of modernist urban design. The attributives added to such spaces - lost, derelict, unused - expressed the negative evaluation of the

\section{References}

Assenmacher (2011) "Berlin-Kreuzberg Prinzessinnengärten_1.jpg.", Wikimedia Commons [online] Available at: https:// commons.wikimedia.org/wiki/File:Berlin-Kreuzberg _ Prinzessinneng\%C3\%A4rten_1.jpg [Accessed: 10 February 2020]

Bishop, P., Williams, L. (2012) "The Temporary City", Routledge, London, UK.

Council of Europe (1986) "Recommendation No. R (86) 11: of the Committee of Ministers to Member States on Urban Open Space", Council of Europe, Strasbourg, France.

de Solá-Morales, I. (1996) "Present and Futures: Architecture in Cities", In: de Solá-Morales, I., Costa, X. (eds.) Present and Futures: Architecture in Cities, ACTAR, Barcelona, Spain, pp. 10-23.

Díez Medina, C., Monclús, J. (2018) "Urban visions: From Planning Culture to Landscape Urbanism", Springer, Cham, Switzerland. https://doi.org/10.1007/978-3-319-59047-9

Fortepan (1980) "1980. Magyarország. Tatabánya, a Tatai út a BudapestGyőr vasútvonal felüljárója után, jobbra a Cementgyári út." (After the overpass of the Budapest-Györ railway line on Tatai út, to the right is Cementgyári út.), [photo archive], 99202, Fortepan, Hungary. [online] Available at: http://www.fortepan. hu/?search=99202 [Accessed: 10 February 2020]

Kim, G. (2016) "The Public Value of Urban Vacant Land: Social Responses and Ecological Value", Sustainability, 8(5), Article Number: 486. https://doi.org/10.3390/su8050486

Kim, G., Miller, P. A., Nowak, D. J. (2018) "Urban vacant land typology: A tool for managing urban vacant land", Sustainable Cities and Society, 36, pp. 144-156. https://doi.org/10.1016/j.scs.2017.09.014

Lefebvre, H. (1991) "The Production of Space", Blackwell, Cambridge, MA, USA. situation. The phenomenon was discovered, but urban designers intended to solve the problem through planning.

By the 1990s - in a period of intensive urban and economic development, which ran parallel with the architects' and urban designers' moral uncertainty - some theoreticians found a new name for the situation: terrain vague. The terrain vague, the vacant space, removed earlier negative connotations, and as a newly discovered place, which was there a long time ago, it now offered the possibility of escape from global capitalism. Following the millennium, there was another change in the approach and evaluation of vacant urban spaces. Systematic research commenced on the characterisation of unused urban spaces, which were no longer unused. Based mainly on practice, the concept of temporary use was born.

Lefebvre, H., Kofman, E., Lebas, E. (1996) "Writings on Cities", Blackwell, Oxford, UK.

Maric, J., Djukic, A. (2018) "Connecting the Centre of Belgrade with the Danube and Sava Riverfronts to Increase Attractiveness", Periodica Polytechnica Architecture, 49(1), pp. 23-28. https://doi.org/10.3311/PPar.11773

Mostafavi, M., Doherty, G. (2010) "Ecological Urbanism", Lars Müller Publishers, Baden, Switzerland.

Nefs, M. (2006) "Unused Urban Space: Conservation or Transformation? Polemics about the Urban Wastelands and Abandoned Buildings", City \& Time, 2(1), pp. 47-58. [online] Available at: http://www. ceci-br.org/novo/revista/docs2005/CT-2005-42.pdf [Accessed: 10 February 2020]

Németh, J., Langhorst, J. (2014) "Rethinking urban transformation: Temporary uses for vacant land", Cities, 40, pp. 143-150. https://doi.org/10.1016/j.cities.2013.04.007

Newman, G. D., Bowman, A. O'M., Jung Lee, R., Kim, B. (2016) "A current inventory of vacant urban land in America", Journal of Urban Design, 21(3), pp. 302-319. https://doi.org/10.1080/13574809.2016.1167589

Oswalt, P., Overmeyer, K., Misselwitz, P. (2013) "Urban Catalyst: The Power of Temporary Use", DOM Publishers, Berlin, Germany. Rowe, C., Koetter, F. (1978) "Collage City", MIT Press, Cambridge, UK. Soja, E. W. (1996) "Thirdspace: expanding the geographical imagination", Blackwell, Cambridge, MA, USA.

Trancik, R. (1986) "Finding Lost Space: Theories of Urban Design", John Wiley \& Sons, New York, NY, USA.

Woolley, H. (2003) "Urban Open Spaces", Spon Press, London, UK. 